\title{
Musculoskeletal Findings, Connective and Soft Tissue Findings Time Point Reference
}

National Cancer Institute

\section{Source}

National Cancer Institute. Musculoskeletal Findings, Connective and Soft Tissue Findings

Time Point Reference. NCI Thesaurus. Code C162210.

The point in time that acts as a fixed reference point to a musculoskeletal finding. 